\title{
SYSTÉM STRATEGICKÉHO POZOROVANIA VO VZŤAHU K FAKTOROM EXTERNÉHO PROSTREDIA A PODNIKOVEJ STRATÉGII
}

\author{
Lucia Demjanová, Štefan Čarnický
}

Kl’účové slová:

strategický manažment, stratégia, prostredie podniku, systém strategického pozorovania, monitorovanie prostredia podniku

\section{Key words:}

strategic management, strategy, business environment, strategic scanning system, monitoring of business environment

\begin{abstract}
Abstrakt
Ciel'om príspevku bolo modelovat' vzt'ah externého prostredia podniku, systému strategického pozorovania a podnikovej stratégie na výskumnej vzorke malých a stredných podnikov z oblasti stavebníctva pôsobiacich na území východného Slovenska. Vytvorili sme model $\mathrm{v}$ podobe diagramu, v ktorom sa nám podarilo potvrdit' existenciu nasledujúcich vzt'ahov:

- medzi vnímaným významom faktorov makroprostredia a externého mikroprostredia a formou využívaného systému strategického pozorovania,

- medzi vnímanou mierou nestability (dynamiky) faktorov makroprostredia a externého mikroprostredia a formou využívaného systému strategického pozorovania,

- medzi formou využívaného systému strategického pozorovania a formou vyjadrenia stratégie.

Náš teoretický model sme nemohli testovat' metódou modelovania štrukturálnych rovníc (SEM - Structural Equation Modelling) z dôvodu nesplnených predpokladov pre túto metódu, ale využili sme metódu CHAID, ktorej výsledkom bol model vo forme rozhodovacieho stromu, ktorý v konečnom dôsledku potvrdil správnost' nami formulovaného teoretického modelu.
\end{abstract}

\footnotetext{
Abstract

The aim of this paper was to model the relationship between the external environment, the system of strategic observation and the corporate strategy on a research sample of small and medium businesses in the field of building and construction industry operating in the area of East Slovakia. We created a model in the form of a diagram, in which we succeeded in confirming the existence of the following relationships:

- Between the perceived significance of factors of macro-environment and the external micro-environment and the form of the applied system of strategic observation,

- Between the perceived rate of instability (dynamics) of the factors of macroenvironment and of the external micro-environment and the form of the applied system of strategic observation,

- Between the form of the applied system of strategic observation and the form of expressing the strategy.

We could not test our theoretical model by the method of modeling structural equations (SEM - Structural Equation Modeling) because of not fulfilled preconditions for this method, but we applied the method CHAID, the result of which was a model in the form of a decision making tree, which in the long run confirmed the correctness of the theoretical model which we formulated.
} 


\section{Úvod}

Orientácia v nestabilných podmienkach, nájdenie správneho smeru a výber vhodnej cesty $\mathrm{k}$ budúcim cielom patria medzi klúčové úlohy strategického manažmentu. Formulovanie vhodnej stratégie je však podmienené efektívnym tokom relevantných informácií o externom prostredí, čo zabezpečuje systém strategického pozorovania. Systém strategického pozorovania umožňuje monitorovanie prostredia podniku a identifikovanie diskontinuít, príležitostí a hrozieb, ktoré môžu ovplyvnit' jeho budúci vývoj a môže existovat' v rôznych podobách. Ciel’om príspevku je analyzovat' externé prostredie a systém strategického pozorovania $\mathrm{v}$ malých a stredných podnikoch východného Slovenska a navrhnút' model vyjadrujúci vzt’ah externého prostredia, systému strategického pozorovania a stratégie podniku.

\section{Teoretické východiská}

Podl'a Shuhuau (1996, s. 2) sú podnik a jeho prostredie úzko previazané, a to samotnými vstupmi a výstupmi. Prostredie alebo okolie podniku sa môže chápat' rozlične, pretože zahŕňa množstvo často nepostrehnutelných vplyvov. Navyše sa tieto vplyvy vyznačujú stochastickost'ou, menlivost'ou $\mathrm{v}$ rozličných časových intervaloch. Zložitost' analýzy prostredia vyplýva d’alej z mnohotvárnosti a komplexnosti prostredia, ktorú analytickými metódami možno posúdit' iba neúplne. Prostredie podniku definujeme ako súbor prvkov, zložiek okolia a ich vzájomných interakcí, ktoré obklopujú a ovplyvňujú podnik, a ktoré i podnik môže čiastočne svojimi aktivitami ovplyvňovat'.

V odbornej literatúre sa môžeme stretnút's viacerými spôsobmi členenia prostredia podniku. Najčastejšie sa v literatúre prostredie podniku delí na makroprostredie a mikroprostredie, resp. odvetvové prostredie (Capps, Hazen, 2002; Kislingerová, Nový, 2005; Kotler, Armstrong, 2004; Kupkovič, 2003; Sedlák, 2007; Vološin, 2003), ale môžeme sa stretnút' aj $\mathrm{s}$ viac-menej odlišnými prístupmi.

Makroprostredie vymedzil Slávik (2005, s. 56) ako prostredie, v ktorom sa nachádzajú všetky podnikatel'ské subjekty nezávisle od konkrétneho odvetvia alebo druhu podnikania. Predstavuje súbor premenných, ktoré pôsobia na všetky podniky rovnako, ale ich dôsledky však môže pocit’ovat' každý podnik odlišne. Makroprostredie pozostáva z rôznych zložiek prostredia, ktorých počet sa líši v závislosti od úrovne dekompozície na jednotlivé časti.

Externé mikroprostredie predstavuje odvetvové prostredie podniku, ktoré je špecifické pre jednotlivé podniky, ale môže byt' čiastočne rovnaké pre podniky pôsobiace $\mathrm{v}$ tom istom odvetví alebo oblasti podnikania. Jeho pôsobenie na podniky je priame a podniky majú väčšie možnosti pri jeho ovplyvňovaní. K analýze odvetvového prostredia sa obvykle využíva Porterov model piatich konkurenčných síl, ktorý pozostáva z piatich faktorov (Porter, 1993, s. 23).

Trhové podmienky postavili pred každý podnik úlohu dokázat' fungovat' a rozvíjat' sa v prostredí neustálych zmien. Strategický manažment vznikol ako reakcia na hl’adanie nových metód riadenia a formovania vývoja podniku v neprestajne sa komplikujúcich podmienkach vonkajšieho prostredia. Na túto skutočnost' poukazuje vo svojej definícii napr. Kreitner (1989, s. 187), ktorý strategický manažment vymedzil ako neustály proces zabezpečovania konkurenčne lepšieho prispôsobenia sa podniku jeho neustále sa meniacemu prostrediu. Podobne na túto skutočnost' poukazuje i Coulter (2004, s. 5) a definuje strategický manažment ako proces pozostávajúci z analýzy súčasnej situácie, tvorby vhodnej stratégie, 
realizácie stratégie a hodnotenia, modifikovania a menenia stratégie, ak je to potrebné. V literatúre sa môžeme potom stretnút' s množstvom definícií, ktoré poukazujú na d'alšie charakteristické znaky strategického manažmentu a obsahujú princípy strategického myslenia.

V súvislosti s procesom strategického manažmentu sa často uvádza sekvenčný model, ktorý pozostáva z formulovania stratégie, implementácie stratégie, hodnotenia a kontroly stratégie (napr. Formisano, 2004; Robbins, Coulter, 2004; Sedlák, 2007; Vološin, 2003).

Čo sa formulácie stratégie týka, je možné uviest' dva krajné prístupy, a to tradičný a moderný. Kým tradičný prístup vychádza z racionálnych úvah a plánovitého poňatia stratégie, moderný prístup zdôrazňuje potrebu prispôsobovat' stratégiu dynamickému prostrediu.

Spravidla $\mathrm{v}$ menších podnikoch je stratégia obsiahnutá v predstavách jednotlivca, ktorý je zároveň tvorcom stratégie. $\mathrm{K}$ tomu, aby stratégia viedla $\mathrm{k}$ dosiahnutiu stanovených ciel'ov a tak zjednocovala úsilie ostatných zamestnancov podniku, je potrebné, aby sa všetci s touto stratégiu adekvátne oboznámili a implementovali ju vo svojich každodenných činnostiach.

Explicitne vyjadrená stratégia je jasne a zrozumitel'ne formulovaná a predpokladá podobu písomného dokumentu, v ktorom sú rozpracované budúce zámery. Explicitne vyjadrená stratégia neplní svoj účel, ak nadobudne len podobu pro forma dokumentu alebo dokonca formu utajovaného dokumentu.

Hintošová (2005, s. 34) uvádza, že jadro stratégie by malo mat' dlhodobý charakter s pravidelnou aktualizáciou približne $\mathrm{v}$ horizonte jedného roka. Preto by mal vrcholový manažment systematicky monitorovat' interné prostredie a zároveň sledovat' zmeny trendov $\mathrm{v}$ externom prostredí podniku. Podobne na význam monitorovania prostredia pre potreby tvorby dynamických stratégií orientovaných na budúcnost' podniku $\mathrm{v}$ nestabilnom prostredí upozorňuje vo svojom príspevku aj Shuhua (1998, s. 302).

Na vývoj externého prostredia môžu podniky reagovat' v zásade dvoma protichodnými typmi strategického správania: reaktívne a proaktívne (Shuhua, 1998, s. 302). Proaktívny typ strategického správania je charakteristický snahou explicitne formulovat' stratégiu a vnútit' ju svojmu okoliu. Tento prístup je príznačnejší pre podniky, ktoré majú dostatok schopností a zdrojov na to, aby mohli neurčitost' vo vývoji prostredia do určitej miery redukovat'. Reaktívny typ strategického správania sa vyznačuje skôr uplatňovaním implicitnej stratégie, ktorá sa pružne prispôsobuje zmenám prostredia, a to predovšetkým prostredníctvom emergentnej stratégie. Tento typ správania je charakteristický najmä pre malé podniky. Dědina a Odcházel (2007, s. 27) sa v tejto súvislosti vyjadrujú o determinizme prostredia, teda že správanie podniku je úplne alebo aspoň z vel'kej miery ovplyvňované a determinované faktormi externého prostredia.

V nadväznosti na vyššie spomínanú potrebu monitorovania prostredia podniku sa d'alej venujeme systému strategického pozorovania (inak nazývanému aj strategický informačný systém), ktorý môže byt' definovaný ako informačný systém, ktorý umožňuje monitorovanie prostredia podniku a identifikovanie diskontinuít, príležitostí a hrozieb, ktoré môžu ovplyvnit' jeho budúci vývoj. Ciel'om systému strategického pozorovania je poskytovat' informácie pre potreby strategického a taktického manažmentu a následne tak zlepšit' schopnost' podniku včas a kompetentne reagovat' na zmeny v prostredí. Audet a d'Amboise (1998, s. 1-3) vo svojej štúdii stanovili aktivity systému strategického pozorovania ako integrovanú súčast’ 
procesu strategického manažmentu a ako jeden z faktorov konkurencieschopnosti malých a stredných podnikov.

V literatúre môžeme nájst' niekol'ko podôb, resp. foriem systému strategického pozorovania. Vološin (2003, s. 115) rozlišuje neformálny a formálny systém strategického pozorovania. Ďalej môžeme podl'a Shuhuau (1996, s. 13) rozlišovat' všeobecné a cielené monitorovanie. Choo (2001) vymedzil štyri spôsoby monitorovania prostredia: nezacielené pozorovanie, podmienené pozorovanie, nariadené pozorovanie a vyhl'adávanie. Drejer (2004) vytýčil tri prístupy k systému strategického pozorovania: top-down prístup, bottom-up prístup a duálny prístup.

El Sawy (1985, s. 57) rozlišuje štyri formy monitorovania prostredia:

- nulová forma pasívneho monitorovania - žiadne monitorovanie - napriek tomu manažéri však získavajú „nevyžiadané“ informácie, ktoré boli získané v rámci bežných aktivít vykonávaných v podniku (nie úmyselne, napr. získanie informácií o ponuke konkurencie pri obchodnom vyjednávaní s potenciálnym zákazníkom),

- reaktívna forma monitorovania - informácie sú vyhl'adávané s ciel’om nájdenia riešenia určitého problému alebo formulovania stratégie,

- náhodná proaktívna forma monitorovania - informácie sú zbierané neustále, ale pozornost' sa sústred'uje na mimoriadne zdroje strategických informácí́,

- systematická proaktívna forma monitorovania - informácie sú zbierané neustále, systematickým spôsobom a pozornost' sa venuje zvyčajným zdrojom strategických informácií. Táto forma môže byt' teda označená ako formalizovaný systém strategického pozorovania.

Určitým vzt'ahom medzi podnikom a jeho prostredím, vplyvom faktorov prostredia podniku na tvorbu stratégie či prípadne využívanie vybraných foriem systému strategického pozorovania sa venovalo viacero výskumných štúdií doma a v zahraničí (Harrington, Lemak, Reed a Kenneth, 2004; Audet a d'Ambois, 1998; OmaraA. El Sawy, 1985; Sutcliffe a Weber, 2005; Choo, 1994; Slávik, Romanová a Grafnetterová, 2004; Olexová a kolektív, 2006), ktorých výsledky ovplyvnili aj prípravu nášho výskumu, formuláciu modelu a následne slúžili pri komparácii výsledkov výskumu.

\section{Materiál a metódy}

Objektom skúmania boli malé a stredné podniky pôsobiace $\mathrm{v}$ odvetví stavebníctva na východnom Slovensku. Ako objekt skúmania bolo vybrané iba jedno odvetvie, ked’že sa skúmalo okrem iného aj odvetvové prostredie. Konkrétne odvetvie stavebníctva bolo zvolené $\mathrm{z}$ viacerých dôvodov. $\mathrm{V}$ prvom rade stavebníctvo zohráva $\mathrm{v}$ rámci slovenského hospodárstva, ale aj v rámci Európskej únie podstatnú úlohu, d’alej je pre toto odvetvie príznačná relatívna vysoká homogénnost' a jednoznačné vymedzenie podl’a odvetvovej klasifikácie činností.

Register podnikov pôsobiacich v odvetví stavebníctva na Slovensku vedie ŠÚ SR, ktorý na základe žiadosti so špecifikovanými kritériami výberu poskytol konkrétny zoznam malých a stredných stavebných podnikov na východnom Slovensku, čo v prípade nášho výskumu predstavovalo základný súbor. Základný súbor pozostával z 1764 podnikov, z ktorých formou jednoduchého náhodného výberu bez opakovania bolo vybraných 320, ktoré boli následne požiadané o účast' vo výskume formou vyplnenia dotazníka. Pri realizácii výskumu bolo použitých niekol'ko spôsobov oslovenia. Využila sa kombinovaná metóda kontaktovania 
telefonicky, osobne a formou listovej zásielky. Výberový súbor po selekcii neúplných dotazníkov pozostával zo 78 podnikov. Návratnost' dotazníka tak predstavuje približne 24 \%.

Ku klasifikácii podnikov podl'a vel'kosti sa pristupovalo s ohl'adom na odporúčania Európskej komisie 2003/361/EC (Commission Recommendation, 2003, L 124/39), pričom však nebolo možné zohl'adnit' ročný obrat a ročnú bilančnú sumu z dôvodu chýbajúcich dát. Následne tak vzorka pozostávala z: 9 mikropodnikov (12\%), 38 malých podnikov (48 \%) a 31 stredných podnikov (40\%).

Reprezentatívnost' výberového súboru bola overovaná porovnaním štruktúry výberového a základného súboru na základe dvoch parametrov, a to právnej formy a geografického umiestnenia podniku. Ďalej bola reprezentatívnost' výberového súboru testovaná chi-kvadrát testom dobrej zhody, ked’ sme štatistickým testovaním potvrdili, že rozdiely medzi základným a výberovým súborom nie sú štatisticky významné. Výberový súbor teda môžeme na základe týchto analýz považovat' za reprezentatívny.

Pri vypracovaní príspevku boli použité všeobecné teoretické metódy spracovania informácií, ako napr. abstrakcia, analýza a syntéza, indukcia a dedukcia. Zo špeciálnych metód sa využili metódy modelovania, štatistické metódy, systémové metódy a komparácia. Pri spracovaní štatistických údajov bol použitý softvér MS Excel a štatistický softvér SPSS a k analýze získaných dát boli použité okrem metód deskriptívnej štatistiky aj metódy induktívne štatistiky, ked’že výberový súbor môžeme považovat' za náhodný a reprezentatívny.

\section{Formulácia modelu}

Model je zjednodušeným obrazom skutočnosti. Prechod od reality k modelu býva však vel'mi zložitý, lebo je potrebné stanovit' mieru abstrakcie tak, aby model odpovedal realite, ale zároveň táto miera nemôže byt' stopercentná. Pri modelovaní vzt'ahu vybraných faktorov externého prostredia $\mathrm{k}$ tvorbe stratégie $\mathrm{v}$ malých a stredných stavebných podnikoch na území východného Slovenska sme sa opierali o teoretické východiská, publikované výsledky výskumov vo forme výskumných štúdií a informácie získané vlastným výskumom.

Formulácia prvotného základného modelu vychádzala prevažne z teoretických poznatkov a sekundárnych informácií, ktoré boli publikované doma a $\mathrm{v}$ zahraničí. Vytýčili sme si tri základné oblasti záujmu, ktoré sme následne považovali za základné prvky modelu, a to stratégiu, resp. typ strategického správania, systém strategického pozorovania a faktory prostredia podniku.

Stratégiu sme vymedzili ako nástroj formovania a plánovania budúceho rozvoja podniku, a preto bola našou ciel'ovou premennou. Náš záujem sme orientovali na formu jej vyjadrenia, ked’že tento údaj v sebe integruje niekol'ko informácí́. V prvom rade, či podniky majú vôbec premyslený a naplánovaný svoj budúci rozvoj. Explicitne vyjadrená stratégia sa môže s väčšou pravdepodobnost'ou viazat' $\mathrm{s}$ plánovitým, preskripčným prístupom a zároveň $\mathrm{s}$ proaktívnym typom strategického správania. Implicitne vyjadrená stratégia môže byt' vo väčšej miere naopak prepojená $\mathrm{s}$ uplatňovaním emergentných stratégií a uprednostňovaním skôr reaktívneho typu strategického správania.

V súvislosti so systémom strategického pozorovania sme vychádzali z predpokladu, že uplatňovaná forma systému strategického pozorovania bude $\mathrm{v}$ priamom vzt'ahu s typom strategického správania, ked’že sme usudzovali, že nulová alebo reaktívna forma systému 
strategického pozorovania sa bude spájat's reaktívnym strategickým správaním, pre ktoré je typické prispôsobovanie sa vonkajším okolnostiam.

Faktory prostredia podniku predstavujú skupiny prvkov prostredia, ktoré ovplyvňujú budúci rozvoj podniku, teda jeho rast, prosperitu a $s$ tým spojené strategické správanie a stratégiu. Vychádzali sme z predpokladu, že komplexnejšie a dynamickejšie vnímané prostredie sa bude spájat's formami systémov strategického pozorovania na kvalitatívne vyššej úrovni. Teda čím väčší bude počet faktorov vyznačujúcich sa silnejším vplyvom na tvorbu stratégie a vyššou mierou premenlivosti prostredia, tým bude využívanejšia sofistikovanejšia forma monitorovania.

Komplexnost' prostredia je $\mathrm{v}$ našom modeli vyjadrená počtom faktorov externého prostredia ovplyvňujúcich tvorbu stratégie a priemernou hodnotou vnímaného významu daných faktorov na formuláciu stratégie $\mathrm{v}$ podniku. Vychádzajúc $\mathrm{z}$ výsledkov analýzy externého prostredia stavebných podnikov na Slovensku bolo respondentom ponúknutých k hodnoteniu 6 faktorov makroprostredia a 5 faktorov externého mikroprostredia. Intenzitu vnímaného vplyvu jednotlivých faktorov pri tvorbe stratégie mohli vyjadrit' na 6 bodovej škále ( 0 - žiaden vplyv, 5 - vel'mi silný vplyv). Faktorová analýza nám potvrdila opodstatnenost' členenia týchto faktorov do skupín, a tak sme využili dekompozíciu celkového faktora komplexnost' prostredia na dve premenné, a to vnímaná komplexnost' makroprostredia a vnímaná komplexnost' externého mikroprostredia.

Dynamika prostredia je v modeli vyjadrená priemernou hodnotou vnímanej miery nestability (turbulentnosti) vybraných faktorov prostredia. Vnímaná dynamika prostredia bola respondentmi hodnotená na 5 bodovej škále $(1$ - stabilné prostredie a 5 - turbulentné prostredie). Opät' sme tu využili výsledky faktorovej analýzy, ktorá aj v tomto prípade potvrdila opodstatnenost' rozdelenia jednotlivých faktorov do skupín. Faktor vnímanej dynamiky prostredia sme rozdelili na dve podkategórie, a to vnímaná dynamika makroprostredia a vnímaná dynamika externého mikroprostredia.

Obrázok 1 zachytáva formulovaný model a znázornené sú na ňom aj hypotézy, ktoré boli formulované s ciel'om jeho overenia.

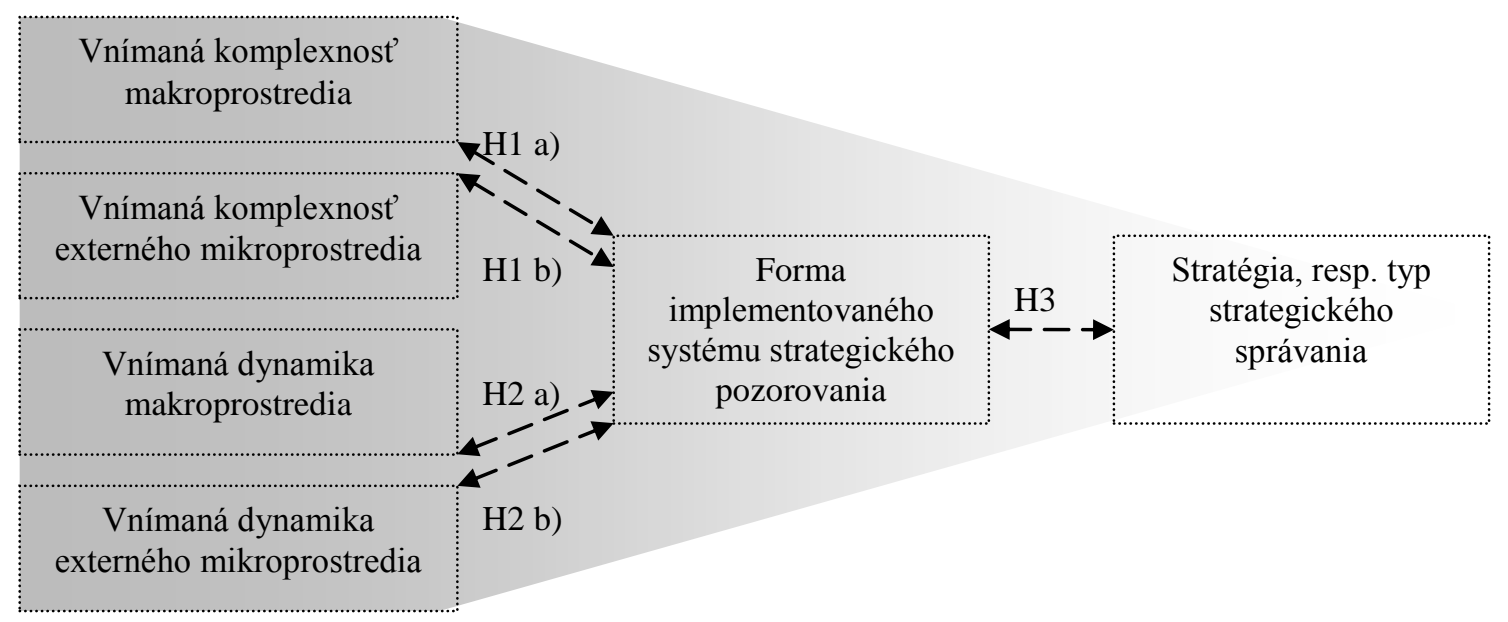

Obr. 1 Model zachytávajúci potenciálne vztahy vybraných faktorov externého prostredia $k$ tvorbe stratégie v malých a stredných stavebných podnikoch na východnom Slovensku 


\section{Overovanie modelu}

K overeniu navrhnutého modelu boli formulované hypotézy H1, H2 a H3, ktoré sa viažu na populáciu malých a stredných stavebných podnikov na východnom Slovensku.

- H1a: Medzi vnímaným významom makroprostredia pri tvorbe stratégie a formou implementovaného systému strategického pozorovania je štatisticky významný vzt’ah.

- H1b: Medzi vnímaným významom externého mikroprostredia pri tvorbe stratégie a formou implementovaného systému strategického pozorovania je štatisticky významný vzt'ah.

- H2a: Medzi vnímanou mierou nestability (turbulencie) makroprostredia a formou implementovaného systému strategického pozorovania je štatisticky významný vzt’ah.

- H2b: Medzi vnímanou mierou nestability (turbulencie) externého mikroprostredia a formou implementovaného systému strategického pozorovania je štatisticky významný vzt'ah.

- H3: Medzi formou implementovaného systému strategického pozorovania a formou vyjadrenia stratégie existuje štatisticky významný vzt’ah.

Hypotézy $\mathrm{H} 1$ a $\mathrm{H} 2$ boli overované prostredníctvom analýzy rozptylu (ANOVA). Testovalo sa, či môžu byt' zistené rozdiely medzi priemermi skupín iba náhodné, alebo sú štatisticky významné. Tabul'ka 1 obsahuje hodnotu Eta koeficientov a P-hodnoty pri jednotlivých hypotézach. Pri štatistickom testovaní týchto hypotéz boli zistené P-hodnoty menšie ako 0,05 , a tak môžeme konštatovat', že nasledujúce hypotézy prijímame.

Tab. 1 Výsledky testovania hypotéz $\mathrm{H} 1$ a $\mathrm{H} 2$

\begin{tabular}{|c|l|r||}
\hline Hypotéza & \multicolumn{1}{|c|}{ Eta koeficient } & P-hodnota \\
\hline $\mathrm{H} 1$ a) & Eta $=0,652-$ silný vzt'ah & $\mathrm{P}=0$ \\
\hline $\mathrm{H} 1 \mathrm{~b})$ & Eta $=0,489-$ stredný vzt'ah & $\mathrm{P}=0$ \\
\hline $\mathrm{H} 2$ a) & Eta $=0,705-$ silný vzt'ah & $\mathrm{P}=0$ \\
\hline $\mathrm{H} 2$ b) & Eta $=0,639-$ silný vzt'ah & $\mathrm{P}=0$ \\
\hline
\end{tabular}

Pri porovnaní výsledkov analyzovaných údajov (Tab. 2) sme došli k týmto zisteniam. Ak bol vplyv faktorov makroprostredia pri tvorbe stratégie hodnotený v priemere vyššími známkami, tak bola v skúmaných podnikoch využívaná reaktívna forma monitorovania alebo kvalitatívne lepšie formy systému strategického pozorovania. V prípade, že vplyv faktorov externého mikroprostredia pri tvorbe stratégie bol hodnotený v priemere vy̌šsími známkami, tak bola uplatňovaná $\mathrm{v}$ podnikoch častejšie nulová forma monitorovania alebo potom $\mathrm{v}$ menšom počte podnikov systematická proaktívna forma monitorovania. 
Tab. 2 Výsledky pri porovnani formy implementovaného systému strategického pozorovania a priemerného hodnotenia faktorov externého prostredia

\begin{tabular}{|c|c|c|c|c|c|c|}
\hline & FISSP & Priemer & $\overline{\mathrm{N}}$ & Šrtand.odch. & Min. & Max. \\
\hline \multirow{6}{*}{$\begin{array}{l}\text { Makroprostredie - hodnotenie významu faktorov } \\
\text { pri tvorbe stratégie }\end{array}$} & 1 & 2,9841 & 21 &, 53724 & 2,33 & 3,67 \\
\hline & 2 & 3,6667 & 12 &, 74874 & 2,50 & 4,33 \\
\hline & 3 & 3,2500 & 24 & ,67566 & 1,67 & 4,00 \\
\hline & 4 & 3,2778 & 9 & ,33333 & 2,83 & 3,50 \\
\hline & 5 & 1,8194 & 12 & ,92239 & ,67 & 3,33 \\
\hline & Spolu & 3,0256 & 78 & ,85958 & ,67 & 4,33 \\
\hline \multirow{6}{*}{$\begin{array}{l}\text { Externé mikroprostredie - hodnotenie významu } \\
\text { faktorov pri tvorbe stratégie }\end{array}$} & 1 & 3,5714 & 21 & ,67018 & 2,60 & $\overline{4,80}$ \\
\hline & 2 & 3,2500 & 12 & 1,31599 & 1,40 & 4,60 \\
\hline & 3 & 3,0583 & 24 & .61709 & 2,20 & 4,40 \\
\hline & 4 & 3,4667 & 9 & 80000 & 2,20 & 4,40 \\
\hline & 5 & 2,1833 & 12 & ,92425 &, 80 & 3,40 \\
\hline & Spolu & 3,1385 & 78 & ,93604 &, 80 & 4,80 \\
\hline \multirow{6}{*}{$\begin{array}{c}\text { Makroprostredie - hodnotenie miery nestability, } \\
\text { dynamiky }\end{array}$} & 1 & 2,8492 & 21 & ,50251 & 1,50 & 3,50 \\
\hline & 2 & 3,5417 & 12 & ,65569 & 2,50 & 4,17 \\
\hline & 3 & 2,8056 & 24 &, 36004 & 2,17 & 3,17 \\
\hline & 4 & 2,6111 & 9 & ,22048 & 2,33 & 2,83 \\
\hline & 5 & 1,8194 & 12 & ,70517 & 1,00 & 2,83 \\
\hline & Spolu & 2,7564 & 78 & ,69303 & 1,00 & 4,17 \\
\hline \multirow{6}{*}{$\begin{array}{l}\text { Externé mikroprostredie - hodnotenie miery } \\
\text { nestability, dynamiky }\end{array}$} & 1 & 3,2857 & 21 & ,42224 & 2,60 & $\overline{4,00}$ \\
\hline & 2 & 3,5000 & 12 & 1,07026 & 2,40 & 4,80 \\
\hline & 3 & 2,9500 & 24 &, 33492 & 2,60 & 3,60 \\
\hline & 4 & 3,1333 & 9 & ,40000 & 2,60 & 3,40 \\
\hline & 5 & 1,9500 & 12 &, 75859 & 1,00 & 3,40 \\
\hline & Spolu & 2,9923 & 78 &, 76034 & 1,00 & 4,80 \\
\hline
\end{tabular}

Pozn.: FISSP - forma implementovaného systému strategického pozorovania (1 - nulová forma pasívneho monitorovania, 2 - reaktívna forma monitorovania, 3 - náhodná proaktivna forma monitorovania, 4-systematická proaktívna forma monitorovania, 5 - respondent sa nevedel vyjadrit')

Vyššie priemerné hodnoty pri hodnotení vnímanej miery nestability faktorov makroprostredia i externého mikroprostredia sa spájali s implementáciou reaktívnych foriem systému strategického pozorovania (t. j. nulová forma monitorovania prostredia a reaktívna forma monitorovania). Z toho môžeme usudzovat', že ak podniky vnímajú faktory externého prostredia ako dynamickejšie, tak s väčšou pravdepodobnost'ou uplatňujú iba reaktívne formy monitorovania.

V súvislosti s vnímaným významom jednotlivých faktorov prostredia a hodnotením miery ich nestability, resp. dynamiky, nás zaujímalo, nakol'ko sú tieto hodnoty korelované. Z korelačnej matice vyplynulo, že pri väčšine faktorov je vzájomne silná pozitívna korelácia, čo znamená, že ak je faktor prostredia hodnotený ako významný pri formulovaní stratégie, tak s pomerne vel'kou pravdepodobnost'ou bude zároveň hodnotený ako faktor s vyššou mierou dynamiky.

Hypotéza H3 „Medzi formou implementovaného systému strategického pozorovania a formou vyjadrenia stratégie existuje štatisticky významný vzt'ah" bola overovaná prostredníctvom Cramerovho kontingenčného koeficientu, ktorého hodnota 0,6 hovorí o existencii silného vzt’ahu a P-hodnota rovná 0 potvrdila tento vzt'ah ako štatisticky významný, čo znamená, že hypotézu H3 prijímame. Grafické zobrazenie daného vzt’ahu je na grafe 1, na základe ktorého je možné konštatovat', že $\mathrm{v}$ malých a stredných stavebných 
podnikoch na východnom Slovensku sú s väčšou pravdepodobnost'ou implementované sofistikovanejšie systémy strategického pozorovania, ked' majú explicitne vyjadrenú stratégiu.

Z výsledkov štatistického testovania na vzorke malých a stredných stavebných podnikov pôsobiacich vo východoslovenskom regióne môžeme usúdit', že modelované vzt'ahy sú významné.

\section{Overovanie modelu s využitím metódy CHAID}

Využitím možností štatistického softvéru a konkrétne metódy CHAID (chi-square automatic interaction detector) sme sa dopracovali $\mathrm{k}$ modelom vo forme rozhodovacích stromov. Metóda CHAID bola publikovaná v roku 1980 Gordonom V. Kassom a môže byt' využitá k predikcii alebo identifikácii interakcií medzi premennými. Často je táto výskumná technika využívaná ako alternatíva viacnásobnej regresie, a to obzvlášt' v prípadoch, ked' súbor dát nie je vhodný k aplikácii regresnej analýzy, čo bol aj náš prípad.

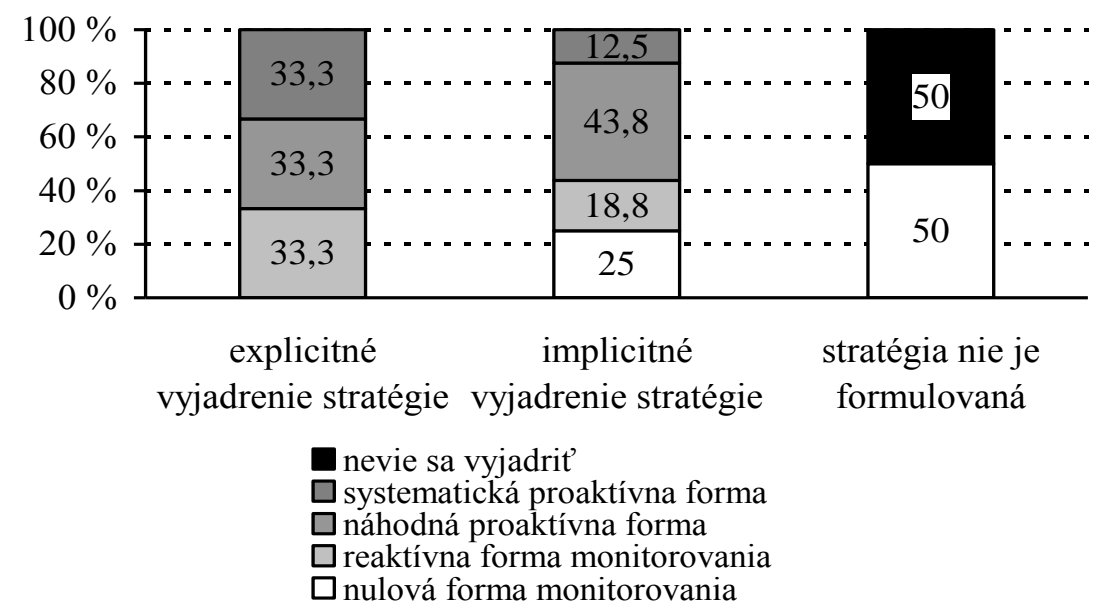

Graf 1 Vztah medzi formou implementovaného systému strategického pozorovania a formou vyjadrenia stratégie

V danom modeli je závislou premennou stratégia (Obr. 2). Pre zjednodušenie modelu sme výsledky ohl'adne formy vyjadrenia stratégie podniku komprimovali do dvoch alternatív: stratégia $\mathrm{v}$ podniku je formulovaná (bez ohl'adu na jej formu) a stratégia $\mathrm{v}$ podniku nie je formulovaná.

Prvou premennou podl'a tohto modelu, ktorá ovplyvňuje formuláciu stratégie v podniku, je implementovaný systém strategického pozorovania, čo korešponduje s naším teoretickým modelom. Ako d’alšia najvýznamnejšia premenná v rozhodovacom strome je vnímaný význam politického a legislatívneho prostredia, teda jeden z faktorov z makroprostredia, čo opät' môžeme považovat' za verifikáciu nášho modelu.

Z rozhodovacieho stromu na obrázku 2 vyplýva, že:

- V prípade, že respondenti nevedeli posúdit', či majú alebo nemajú implementovaný systém strategického pozorovania, tak nemali formulovanú ani stratégiu podniku.

- Ak respondenti uviedli, že v podniku majú implementovanú niektorú z proaktívnych foriem monitorovania alebo reaktívnu formu monitorovania, tak išlo o podniky, ktoré mali zároveň vytvorenú aj podnikovú stratégiu. 
- Ak respondenti uviedli nulovú formu monitorovania prostredia, tak s približne $57 \%$ pravdepodobnost'ou mali formulovanú stratégiu podniku. Vysvetl'ujúcou premennou bolo v tomto prípade softvérom označené politické a legislatívne prostredie.

- Ak podniky hodnotili význam politického a legislatívneho prostredia pri formulácii stratégie známkou vyššou ako 3, tak nemali formulovanú stratégiu $\mathrm{v}$ podniku.

- Ak podniky hodnotili politické a legislatívne prostredie stredným alebo slabším vplyvom, tak mali formulovanú stratégiu podniku.

\section{Záver}

Opierajúc sa o teoretické východiská a výsledky výskumov domácich a zahraničných štúdií sme sa pokúsili formulovat' teoretický model v podobe diagramu, ktorý by zachytával vzt'ah vybraných faktorov externého prostredia, formy systému strategického pozorovania a formulácie stratégie. Vytýčili sme hypotézy, ktorých štatistickým overením sme potvrdili existenciu vzt’ahov medzi vytypovanými premennými, čím sme potvrdili vhodnost' zostaveného modelu. K overeniu sme využili i metódu CHAID, ked' softvér analyzoval vzt’ahy medzi všetkými skúmanými premennými k stanovenej závislej premennej a zostavil model $\mathrm{v}$ podobe rozhodovacieho stromu, $\mathrm{v}$ ktorom identifikoval najvýznamnejšie premenné ovplyvňujúce vybranú závislú premennú. Model v podobe rozhodovacieho stromu korešpondoval s naším teoretickým modelom. Identifikovanie týchto väzieb môže rozširovat' poznatky nielen na teoretickej úrovni, ale tieto poznatky môžu byt' tiež východiskom pri návrhu vhodných foriem systému strategického pozorovania v podnikovej praxi jednotlivých ekonomických subjektov. 


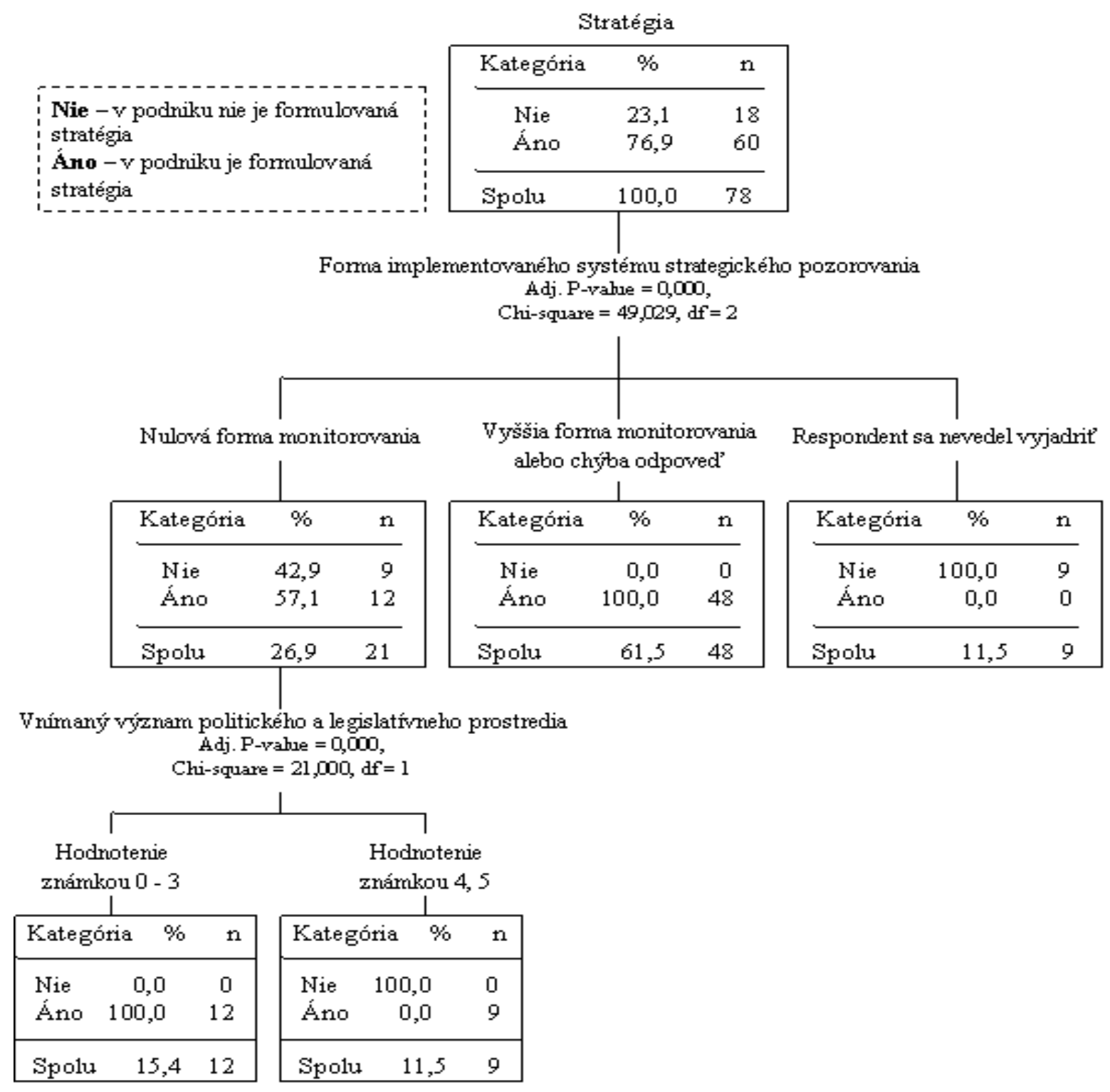

Obr. 2 Model vo forme rozhodovacieho stromu, ked' je ako závislá premenná stanovená existencia stratégie v podniku

\section{Literatúra:}

[1] AUDET, J. - d'AMBOISE, G. 1998. The relationship between strategic scanning activities of small and medium-sized enterprises and their performance: a multi-site study approach. b. m. : b. v. 10 s. [cit. 20.1.2007] Dostupné na internete: <http://www.usasbe.org/knowledge/proceedings /1998/37-audet.pdf>

[2] CAPPS, CH. J. III - HAZEN, S. E. 2002. Applying General Systems Theory to the Strategic Scanning of the Environment from 2015 to 2050 [online]. In: International Journal of Management, roč. 19, 2002, č. 2, s. 308 - 314. [cit. 5.9.2007] Dostupné na internete: <http://proquest.umi.com/pqdweb?index=1\&did=923308771\& SrchMode $=1 \&$ sid $=1 \&$ Fmt $=6 \&$ VInst $=$ PROD $\& V T y p e=P Q D \& R Q T=309 \& V N a m e=P Q D$ $\& \mathrm{TS}=1188987208 \&$ clientId $=57746>$

[3] Commission recommendation of 6 May 2003 concerning the definition of micro, small and medium-sized enterprises [online]. 2003. Brusel : b. v. 6 s. [cit. 3.3.2008] Dostupné 
na internete: <http://europa.eu/eur-lex/pri/en/oj/dat/2003/1_124/1_124200 30520en 00360041.pdf>

[4] COULTER, M. 2004. Strategic management in action. 3. vyd. New Jersey : Prentice Hall. 350 s. ISBN 0-13-129388-5

[5] DĚDINA, J. - ODCHÁZEL, J. 2007. Management a moderní organizování firmy. Praha : Grada Publishing. 328 s. ISBN 978-80-247-2149-1

[6] DREJER, A. - OLESEN, F. - STRANDSKOV, J. 2005. Strategic scanning in a new competitive ladscape : towards learning approach [online]. In: International Journal of Inovation and Learning, roč. 2, 2005, č. 1, s. 47 - 64. ISSN 1741-8089 [cit. 17.1.2007] Dostupné na internete: <http://www.inderscience.com/storage/ f114986352107121.pdf>

[7] DREJER, A. 2004. Strategic Scanning and learning in the new competitive ladscape - a learning approach [online]. b. m. : b. v. 34 s. [cit. 17.1.2007] Dostupné na internete: <http://swoba.hhs.se/aardom/abs/aardom2004_011.htm>

[8] EL SAWY, O. A. 1985. Personal Information Systems for Strategic Scanning in Turbulent Environments: Can the CEO Go ON-Line? [online]. In: MIS Qarterly, roč. 9. 1985, č. 1, s. 53-60. [cit. 5.9.2007] Dostupné na internete: <http://web.ebscohost. $\mathrm{com} /$ ehost/pdf?vid=4\&hid=7\&sid=f2f126f9-5948-487f-903c-

1048c563e9\%40SRCSM1>

[9] FORMISANO, R. A. 2004. Manager's Guide to Strategy. New York : McGraw-Hill. 224 s. ISBN 0-07-143645-6

[10] HINTOŠOVÁ, A. 2005. Jak vytvořit podnikovou strategii. In: Moderní řizení, roč. XL, 2005, č. 12 , s. 33 - 35. ISSN 0026-8720

[11] CHOO, Ch. W. 1994. Perception and Use of Information Sources by Chief Executives in Environmental Scanning [online]. In: Library and Information Science Research, roč. 16, 1994, č. 1, s. 23 - 40. ISSN-0740-8188 [cit. 13.3.2008] Dostupné na internete: <http://choo.fis.utoronto.ca/fis/ResPub/LISR.html>

[12] CHOO, Ch. W. 2001. Environmental scanning as information seeking and organizational learning [online]. In: Information Research, roč. 7, 2001, č. 1. [cit. 13.3.2008] Dostupné na internete: <http://InformationR.net/ir/7-1/paper112.html>

[13] KISLINGEROVÁ, E. - NOVÝ, I. a kol. 2005. Chování podniku v globalizujícím se prostredí. Praha: C. H. BECK. 422 s. ISBN 80-7179-847-9

[14] KOTLER, P. - ARMSTRONG, G. 2004. Marketing. Praha : Grada Publishing. 856 s. ISBN 80-247-0513-3

[15] KREITNER, R. 1989. Management. 4. vyd. Boston : HOUGHTON MIFFLIN COMPANY. 847 s. ISBN 0-395-38106-1

[16] KUPKOVIČ, M. a kol. 2003. Podnikové hospodárstvo : Komplexný pohl’ad na podnik. 7. vyd. Bratislava : Sprint vfra. 452 s. ISBN 80-88848-71-7

[17] OLEXOVÁ, C. a kol. 2006. Nové trendy riadenia l’udských zdrojov v znalostnej spoločnosti : Záverečné hodnotenie internej grantovej úlohy č. 2330256/06. Košice : Katedra manažmentu PHF EU.60 s.

[18] PORTER, M. E. 1993. Konkurenční výhoda : (Jak vytvořit a udržte si nadprůměrný výkon). Praha : Victoria Publishing. 626 s. ISBN 80-85605-12-0

[19] ROBBINS, S. P. - COULTER, M. 2004. Management. Praha : Grada Publishing. 600 s. ISBN 80-247-0495-1

[20] SEDLÁK, M. 2007. Manažment. 3. vyd. Bratislava : IURA EDITION. 360 s. ISBN 978-80-8078-133-0

[21] SUTCLIFFE, K. M. - WEBER, K. 2005. Executive information search, perceptual accuracy and firm performance [el. verzia]. b. m. : b. v. 52 s. [cit. 11.2.2008] Dostupné na internete: <http://web.mit.edu/sloan/osg-seminar/s05_docs/ accompanying\% 20papers/sutcliffe\%20mit\%20talk.pdf > 
[22] SHUHUA, L. 1996. Strategic Scanning and Interpretation: the Organization, Strategic Management and Information Processing Context [online]. Turku : TUCS. 37 s. ISBN 951-650-927-4 ISSN 1239-1891 [cit. 14.2.2007] Dostupné na internete: <www.tucs.fi/publications/attachment.php?fname= TR84.ps.gz>

[23] SHUHUA, L. 1998. Strategic scanning and interpretation revisiting: foundations for a software agent support system - Part 1: understanding the concept and context of strategic scanning [online]. In: Industrial Management \& Data Systems, 1998, č. 7, s. 295 - 312. ISSN 0263-5577 [cit. 5.9.2007] Dostupné na internete: $<$ http://web.ebscohost.com/ehost/pdf?vid=4\&hid=7\&sid =f2f126f9-5948-487f-903c9a1048c563e9\%40SRCSM1>

[24] SLÁVIK, Š. 2005. Strategický manažment. Bratislava : SPRINT. 403 s. ISBN 8089085-49-0

[25] SLÁVIK, Š. - ROMANOVÁ, A. - GRAFNETTEROVÁ, M. 2004. Meranie turbulencie podnikatel'ského prostredia. In: Ekonomika a manažment, roč. I, 2004, č. 1, s. 28 - 41. ISSN 1336-3301

[26] VOLOŠIN, M. 2003. Strategický manažment podniku. Bratislava : EKONÓM. 208 s. ISBN 80-225-1628-7

Klasifikace JEL: M10, M15

Ing. Lucia Demjanová, PhD.

Odborná asistentka Katedra manažmentu

Podnikovohospodárska fakulta v Košiciach

Ekonomická univerzita v Bratislave

Tajovského 13, 04130 Košice

lucia.demjanova@euke.sk

Doc. Ing. Štefan Čarnický, PhD.

Docent Katedra manažmentu

Podnikovohospodárska fakulta v Košiciach

Ekonomická univerzita v Bratislave

Tajovského 13, 04130 Košice

stefan.carnicky@euke.sk 